\title{
TREE LILAC CULTIVARS TESTED AS STREET TREES: INITIAL RESULTS
}

\author{
by Henry D. Gerhold
}

\begin{abstract}
Three Japanese tree lilac (Syringa reticulata) cultivars, 2 each in 11 communities, were planted for evaluation as street trees. Cooperators in the Municipal Tree Restoration Program using standardized methods measured them annually for 3 years, and periodically afterwards. 'Ivory Silk', 'Regent', and 'Summer Snow' performed well at all locations. All 3 cultivars grew slowly initially, and their foliage tended to turn yellow in late summer. Height growth of 'Summer Snow', reputed to be slower than 'Ivory Silk', was not slower at all locations.
\end{abstract}

Key Words. Tree lilac; Syringa reticulata; 'Tvory Silk'; 'Regent'; 'Summer Snow'; street trees; performance testing.

Japanese tree lilac (Syringa reticulata) cultivars are being evaluated as part of the Municipal Tree Restoration Program. MTRP encourages municipalities to improve their tree programs and provides information to help decision-makers select appropriate cultivars for planting under utility wires. Free trees purchased with utility funds serve as an incentive for communities to participate. Initial results of performance tests of crabapple (Malus), Callery pear (Pyrus calleryana), and serviceberry (Amelanchier) cultivars were reported previously (Gerhold et al. 1994; Gerhold and McElroy 1994; Gerhold 1999).

Earlier research comparing landscape trees (Reisch et al. 1971; Ticknor 1971; Mower 1973; and Kozel 1974) led to the proposal of a cooperative performance testing system for street tree cultivars (Gerhold and Bartoe 1976; Gerhold 1985). The statistical design was based on measurements of 23 cultivars supplied by municipal arborists in Iowa, Michigan, Ohio, Pennsylvania, Vermont, and Washington (Bartoe 1977).

\section{METHODS}

Ten communities in Pennsylvania and 2 in New York planted the tree lilacs represented in this report. Community representatives chose the planting sites with assistance from utility foresters, service foresters, and Extension urban foresters; 2 of these usually assisted each community. A typical cultivar performance test consisted of 2 cultivars planted alternately within 4 to 10 plots that could contain 4 to 16 trees each, a total of 50 trees. All test trees were planted along streets and under electric conductors; the utility company arranged for removal of large trees that interfered with utility lines. Both cultivars for a community were ordered $B \& B$ from the same nursery, with calipers of 4.4 to $5.1 \mathrm{~cm}$ (1.75 to $2 \mathrm{in}$.); heights ranged from 2.4 to $3.7 \mathrm{~m}$ ( 8 to $12 \mathrm{ft}$ ).

The cultivar tests were planted between 1987 and 1996. A trained cooperator inspected and measured the trees annually during the first 3 years, and then at 3-year intervals in most cases. During September or October, a service forester or Extension urban forester used standardized methods to measure tree height, trunk diameter, and crown width, and to classify foliage health, branch health, trunk health, maintenance needs, and overall quality. Causes of damage such as disease, insects, drought, and mechanical injuries also were recorded.

An analysis of variance (MINITAB General Linear Model) was conducted on each type of quantitative data from the 2 cultivars in a community to calculate means and determine significance of differences. Each test location in every year was treated as a separate experiment with plots providing replication. These results, along with written comments of cooperators, were used to characterize performance of the cultivars.

\section{RESULTS}

At most locations, the tree lilacs grew slowly for the first 3 or more years, and then the rate of height and diameter growth increased. The pattern of growth at Corry was typical of most locations (Figure 1); only at Lebanon did more rapid growth start in the second year after planting. Survival rates 6 or 9 years after planting were $88 \%$ to $100 \%$ at all locations, except one where trees were vandalized. 
Significant differences between cultivars in trunk diameter, tree height, and crown width were found at several locations (Table 1). In some cases (Corry and Camp Hill), these differences already were present at the time of planting, indicating they were not matched in size when they left the nursery. In the remaining comparisons the size differences were modest, except at Westfield where 'Ivory Silk' was $1.5 \mathrm{~m}(5 \mathrm{ft})$ taller than 'Summer Snow' 9 years after planting.

The foliage of all 3 cultivars tended to turn yellow in late summer before other species showed fall colors. The yellowing occurred especially on more stressful sites, whereas individual trees that had been well watered or growing in spacious areas remained green longer. Some cooperators regarded yellow leaves to be a sign of poor health. For this reason, foliage health ratings below 4.0 (more than $20 \%$ of foliage affected) were common, but there were few significant differences between cultivars and no severe disease or insect injuries.

Differences among cultivars in branch health, trunk health, and maintenance needs (not shown) were uncommon and transient. They were caused mainly by mechanical damage. Dieback of terminal branches commonly occurred during the first few years as trees were becoming established.

Overall ratings also were variable, inconsistent, and generally differed by less than 1.0. However at Athens, 'Summer Snow' was consistently rated above 'Ivory Silk'. The service forester who measured these trees reported that he liked the yellow foliage of 'Summer Snow', which turned color earlier, and its somewhat larger, more robust crowns.

\section{CONCLUSIONS}

All 3 cultivars performed well, including 'Summer Snow', which is reputed to be slower growing but was not at all locations. The initial slow growth and even some dieback of these cultivars was the only real disadvantage, compared to other species used as street trees. The tendency of foliage to turn yellow before the onset of fall coloration by other species is perceived as a sickly appearance by some, but alternatively may be regarded as an attraction in the landscape.

\section{LITERATURE CITED}

Bartoe, D.W., II. 1977. Statistical designs for evaluating and comparing street tree cultivars. M.S. thesis, Penn State Univ., University Park PA 16802. 98 pp.

Gerhold, H.D. 1985. Performance testing of street tree cultivars: A model project. J. Arboric. 11(9):263-271.

Gerhold, H.D. 1999. Serviceberry cultivars tested as street trees: Initial results. J. Arboric. 25(4): 189-192.

Gerhold, H.D., and W.D. Bartoe II. 1976. Performance testing tree cultivars in metropolitan environments. J. Arboric. 2(12):221-227.

Gerhold, H.D., and H.L. McElroy. 1994. Callery pear cultivars tested as street trees: Initial results. J. Arboric. 20(5):259-261.

Gerhold, H.D., H.L. McElroy, and H.L.H. Rhodes. 1994. Street tree performance tests of crabapple cultivars: Initial results. J. Arboric. 20(2):87-93.

Kozel, P.C. 1974. Shade trees for suburban and city arboriculture. HortScience 9(6):515-518.

Mower, R.G. 1973. Some observations on street tree plantings. Proc. Intl. Shade Tree Conf. 49:49-55.

Reisch, K.W., G. Hull, and H.M. Hill. 1971. Case histories of several street tree species and cultivars at selected sites in five Ohio cities. Ohio Agric. Res. Dev. Ctr., Hort. Dept. Series 376, 65 pp.

Ticknor, R.L. 1971. Landscape tree performance. Oregon State Univ., Agric. Exp. Sta., Circular of Information 633, $11 \mathrm{pp}$

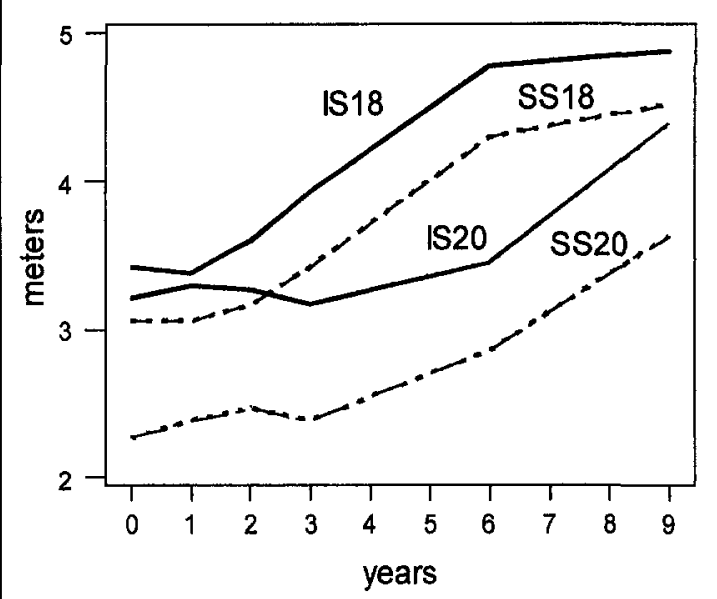

Figure 1. Height growth of 'Ivory Silk' (IS) and 'Summer Snow' (SS) tree lilacs at Lebanon (Test 18) and Corry (Test 20). 
Table 1. Growth, health, and overall ratings of Japanese tree lilac cultivars, derived from data collected until the second year to the tenth year after planting. Average trunk diameter, tree height, and crown width are in the most advanced year; foliage health, branch health, and overall ratings are averaged over all years.

\begin{tabular}{llcclllll}
\hline \multirow{2}{*}{ Cultivar } & Location & Year & $\begin{array}{l}\text { Diameter } \\
\mathrm{cm}\end{array}$ & $\begin{array}{l}\text { Height } \\
\mathrm{m}\end{array}$ & $\begin{array}{l}\text { Width } \\
\mathrm{m}\end{array}$ & $\begin{array}{l}\text { Foliage } \\
1-5^{\mathrm{z}}\end{array}$ & $\begin{array}{l}\text { Branches } \\
1-5^{\mathrm{z}}\end{array}$ & $\begin{array}{l}\text { Overall } \\
1-9^{y}\end{array}$ \\
\hline "Ivory Silk' & Westfield & 10 & 9.0 & $5.9^{\mathrm{x}}$ & 3.6 & 4.3 & 4.6 & 7.8 \\
& Athens & 9 & 6.0 & 3.8 & $1.7^{\mathrm{x}}$ & 3.9 & 4.6 & $4.6^{\mathrm{w}}$ \\
& Lebanon & 9 & 12.9 & 4.9 & 2.8 & 3.4 & 3.8 & 5.6 \\
& Corry & 9 & $6.8^{\mathrm{x}}$ & $4.4^{\mathrm{x}}$ & 2.6 & 3.3 & 3.9 & 4.5 \\
& Waverly NY & 6 & 5.2 & 3.2 & - & 4.2 & 4.2 & 6.4 \\
& Shinglehouse & 6 & $6.2^{\mathrm{x}}$ & 4.1 & $2.3^{\mathrm{x}}$ & 3.6 & 4.8 & 5.5 \\
& Patton & 6 & 6.0 & 3.8 & 2.0 & 3.7 & 4.4 & 5.3 \\
& Hollidaysburg & 6 & 6.2 & 3.9 & 2.2 & 3.9 & 4.6 & 5.8 \\
& Wyomissing & 3 & 4.8 & 3.4 & 1.6 & 3.3 & 3.6 & 5.9 \\
'Regent' & Dauphin & 2 & 4.1 & 3.4 & $1.8^{\mathrm{x}}$ & 4.7 & 4.9 & 9.0 \\
& Camp Hill & 2 & $3.8^{\mathrm{x}}$ & $3.5^{\mathrm{x}}$ & $1.3^{\mathrm{x}}$ & $4.8^{\mathrm{x}}$ & 5.0 & 9.0 \\
& Waverly NY & 6 & 5.1 & 3.2 & - & 4.2 & 4.3 & 6.4 \\
& Shinglehouse & 6 & $5.4^{\mathrm{x}}$ & 3.9 & $2.0^{\mathrm{x}}$ & 4.1 & 4.6 & 5.5 \\
& Patton & 6 & 6.4 & 3.8 & 1.9 & 3.9 & 4.4 & 5.3 \\
& Wyomissing & 3 & 4.8 & 3.3 & 1.6 & 3.4 & 3.7 & 6.1 \\
& Dauphin & 2 & 4.5 & 3.2 & $1.4^{\mathrm{x}}$ & 5.0 & 5.0 & 9.0 \\
& Westfield & 10 & 8.2 & $4.4^{\mathrm{x}}$ & 3.3 & 4.3 & 4.6 & 8.0 \\
& Athens & 9 & 7.3 & 3.9 & $2.0^{\mathrm{x}}$ & 3.9 & 4.5 & $6.0^{\mathrm{w}}$ \\
& Lebanon & 9 & 11.6 & 4.5 & 3.3 & 3.3 & 3.8 & 5.2 \\
& Corry & 9 & $4.8^{\mathrm{x}}$ & $3.6^{\mathrm{x}}$ & 2.6 & 2.5 & 3.8 & 4.1 \\
& Hollidaysburg & 6 & 6.4 & 3.9 & 2.2 & 3.8 & 4.5 & 5.8 \\
& Camp Hill & 2 & $3.5^{\mathrm{x}}$ & $2.7^{\mathrm{x}}$ & $1.4^{\mathrm{x}}$ & $4.9^{\mathrm{x}}$ & 5.0 & 9.0 \\
\hline
\end{tabular}

${ }^{2}$ Foliage and branch injury ratings: $1=65 \%$ to $100 \%, 2=45 \%$ to $60 \%, 3=25 \%$ to $40 \%, 4=5 \%$ to $20 \%, 5=$ less than $5 \%$.

YOverall ratings: $0=$ unsuitable to $9=$ ideal.

${ }^{x}$ Cultivars at the same location differ significantly at the $95 \%$ level.

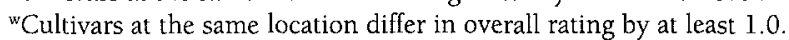


Acknowledgements. Financial support for the $\mathrm{Mu}-$ nicipal Tree Restoration Program was provided by utility companies through the Pennsylvania Electric Energy Research Council and by donations of arboricultural firms: ACRT, Allegheny Power Systems, Asplundh Tree Expert Co., Bartlett Tree Expert Co., Davey Tree Expert Co., Duquesne Light, Environmental Consultants Inc., GPU Energy, Hazlett Tree Service, Penn Power, Pennsylvania Power \& Light, and UGI Corporation. Service Foresters of the Pennsylvania Bureau of Forestry and the New York Department of Environmental Conservation, and Extension Urban Foresters of Penn State University assisted with community liaison and tree measurements.

\section{Professor of Forest Genetics \\ School of Forest Resources \\ Penn State University \\ 109 Ferguson Building \\ University Park, PA 16802}

Résumé. Trois cultivars de lilas japonais en arbre, deux de chacun dans 11 communautés, ont été plantés pour être évalués comme arbres de rues. Des collaborateurs du Programme municipal d'arbres de restauration les ont mesuré annuellement durant trois ans, et périodiquement par après au moyen de méthodes standardisées. Les cultivars Ivory Silk, Regent, et Summer Snow ont bien fonctionné dans toutes les localités. Les trois ont poussé lentement au début et leur feuillage tendaient à devenir jaune tard en automne. La croissance en hauteur de Summer Snow, réputée pour être plus lente que Ivory Silk, n'était pas lente dans aucune des localités.

Zusammenfassung. Drei chinesische Fliederarten, jeweils zwei aus elf Gemeinden, wurden gepflanzt, um ihre Tauglichkeit als Strassenbäume zu bewerten. Mitarbeiter des kommunalen Baumpllanzprogramms unternahmenn unter Verwendung standartisierter Methoden jährlich für einen Zeitraum von drei Jahren und in periodischen Abständen hinterher Messungen. Ivory Silk, Regent und Summer Snow entwickelten sich an allen Standorten am besten. Alle drei wuchsen zu Anfang langsam und ihr Laub tendierte dazu, gegen Ende des Sommers gelb zu werden. Das Höhenwachstum von Summer Snow, welches angeblich hinter Ivory Silk zurückbleiben sollte, war an allen Standorten nicht langsamer.

Resumen. Tres cultivares del árbol lila japonés, dos en cada una de once comunidades, fueron plantados para su evaluación como árboles urbanos. Fueron medidos anualmente por tres años en cooperación con el Programa de Restauración de Arboles Municipales usando métodos estándar, y después periódicamente. 'Ivory Silk', 'Regent' y 'Summer Snow' funcionaron bien en todas las localidades. Todos los árboles crecieron lentamente al inicio, y su follaje tendió a hacerse amarillento en el verano tardío. Ocho crecimientos de 'Summer Snow', que tienen la reputación de ser menores que 'Ivory Silk', no lo fueron asi en todas las localidades. 